\title{
PENGARUH MEDIA AUDIO VISUAL DAN MEDIA LEAFLET TERHADAP TINGKAT PENGETAHUAN REMAJA MAS DARUL IHSAN ACEH BESAR TENTANG HIV/AIDS
}

\author{
Cut Yuniwati, Yusnaini, Khusnul Khatimah \\ Poltekkes Kemenkes Aceh
}

\begin{abstract}
Abstrak
Kejadian HIV/AIDS masih menjadi masalah global. Perkembangan seks terjadi karena pengaruh negatif dari luar dengan disertai tipisnya iman dan kosongnya pendidikan agama, diikuti dengan kesenangan sesaat dan cara berfikir yang belum dewasa sehingga timbulnya pemikiran yang gelap dan perilaku yang menyimpang seks sebelum menikah. Tahun 2015, sebanyak 36,7 juta penduduk dunia terkena HIV dan 1,1 juta terkena AIDS. Sekitar 5700 orang terkena HIV setiap harinya. Indonesia merupakan negara dengan angka kejadian HIV/AIDS yang cukup tinggi.. Peningkatan pengetahuan remaja tentang HIV/AIDS dapat dilakukan dengan kegiatan penyuluhan kesehatan. Penelitian ini bertujuan untuk mengetahuipengaruh media audio visual dan media leaflet terhadap tingkat pengetahuan remaja MAS Darul Ihsan tentang HIV/AIDS.Penelitian ini bersifat analitik dengan jenis penelitian quasi experiment menggunakan rancangan pretest-posttest group design.Sampel dalam penelitian ini adalah remaja MAS Darul Ihsan sebanyak 186 orang. Dimana 93 orang kelompok Media Audio Visual dan 93 orang kelompok Media Leaflet.Hasil uji statistik menunjukkan bahwa sig $=0,137(0,137>0,05)$, maka Ho diterima. Jadi, dapat disimpulkan bahwa tidak ada perbedaan antara rata-rata tingkat pengetahuan kelompok audiovisual dengan kelompok leaflet sebelum dan sesudah intervensi.
\end{abstract}

Kata kunci : Media Audio Visual, Media Leaflet, Pengetahuan HIV/AIDS, Remaja

\section{LATAR BELAKANG}

Masa remaja merupakan periode terjadinya perubahan dan perkembangan yang pesat baik secara fisik, psikologis maupun intelektual. Remaja adalah penduduk dalam rentang usia 10-19 tahun1. Remaja adalah penduduk dalam rentang usia 10-18 tahun2 dan rentangusia remaja adalah 10-24 tahun dan belum menikah $^{3}$.

Kesehatan reproduksi adalah suatu keadaan fisik, mental dan sosial yang utuh, bukan hanya bebas dari penyakit kecacatan dalam segala aspek yang berhubungan dengan sistem reproduksi, fungsi serta prosesnya $^{4}$. Kesehatan reproduksi merupakan suatu keadaan dimana manusia dapat menikmati kehidupan seksualnya serta mampu menjalankan fungsi dan proses reproduksinya secara sehat dan aman ${ }^{5}$.

Kejadian HIV/AIDS masih menjadi masalah global. Pada tahun 2015, sebanyak 36,7 juta penduduk dunia terkena HIV dan 1,1 juta terkena AIDS. Sekitar 5700 orang terkena HIV setiap harinya. Indonesia merupakan negara dengan angka kejadian HIV/AIDS yang cukup tinggi. Pada tahun 2005-2015, kejadian kasus HIV semakin meningkat, pada 10 tahun terakhir ditemukan ada 184.929 kasus HIV/AIDS yang dilaporkan. Jumlah kasus HIV tertinggi yaitu DKI Jakarta (38.464 kasus), diikuti Jawa Timur (24.104 kasus), Papua (20.147 kasus), Jawa Barat (17.075 kasus), Jawa Tengah (12.267 kasus). Sedangkan di Aceh pada tahun 2014 sampai dengan Mei 2017 terdapat sebanyak 318 kasus dan khususnya di Aceh Besar terdapat 33 Kasus $^{6}$.

Menurut jenis kelamin, persentase kasus baru AIDS tahun 2015 pada kelompok laki-laki 2,1 kali lebih besar dibandingkan pada kelompok perempuan. Gambar diatas menunjukkan, proporsi penderita AIDS pada laki - laki lebih tinggi sebesar $67 \%$ yaitu sebanyak 35 kasus dibandingkan pada perempuan sebesar 33\% (17 kasus) ${ }^{6}$.

Gambaran kasus baru AIDS di Aceh menurut kelompok umur menunjukkan bahwa sebagian besar kasus AIDS terdapat pada usia 25 sampai dengan 49 tahun yaitu sebanyak 47 kasus atau sebesar 90\%. Proporsi seluruh kematian akibat AIDS sebanyak 17 orang yaitu $65 \%$ pada laki - laki dan $35 \%$ perempuan. Sedangkan di Kabupaten aceh Besar dari tahun 2014 sampai Mei 2017 terdapat sebanyak 33 kasus.Berdasarkan usia kasus HIV/AIDS di Indonesia paling banyak diderita oleh usia produktif 25-49 tahun, dan usia remaja 15-19 tahun menduduki posisi kelima $^{10}$. Usia remaja merupakan usia yang sangat rentang untuk terinfeksi HIV. Lebih dari setengah infeksi baru HIV didunia ditemukan pada usia 15-19 tahun, dan mayoritas remaja terinfeksi karena hubungan seksual ${ }^{7}$. 
Metode pendidikan massa bertujuan untuk mengkomunikasikan pesan-pesan kesehatan yang ditujukan kepada masyarakat yang sifatnya massa atau publik, maka cara yang paling tepat pendekatan massa. Menurut para ahli, indera yang paling banyak menyalurkan pengetahuan ke dalam otak adalah mata. Kurang lebih $75 \%$ sampai $87 \%$ dari pengetahuan manusia diperoleh, disalurkan melalui mata. Sedangkan 13\% sampai 25\% lainnya tersalur melalui inderalain. Dari sini dapat disimpulkan bahwa alat-alat visual lebih mempermudah cara penyampaian dan penerimaan informasi atau bahan pendidikan ${ }^{3}$.

Berdasarkan survei pendahuluan, MAS Darul Ihsan belum pernah terpapar tentang HIV/AIDS, sementara remaja putra dan putri yang di kelas Aliyah didominasi usia 15 tahun ke atas. Pada masa ini adalah masa transisi dari remaja menuju dewasa yang merupakan masa krisis apabila tidak dibimbing bisa mengarah pada perilaku yang beresiko. Oleh karena itu, peneliti tertarik untuk melakukan penelitian dengan judul "Pengaruh Media Audio Visual Dengan Media Leafleat Terhadap Tingkat Pengetahuan Remaja MAS Darul Ihsan tentang HIV/AIDS”.

\section{METODE}

Penelitian ini bersifat analitik dengan jenis penelitian quasi experiment menggunakan rancangan pretest-posttest group design.Sampel dalam penelitian ini adalah remaja MAS Darul Ihsan sebanyak 186 orang. Dimana 93 orang kelompokMediaAudio Visual dan 93 orang kelompok Media Leaflet.

Pemberian perlakuan dilakukan selama 1 kali. Sebelum diberikan perlakuan, responden diberikan soal pretest dan setelah diberikan perlakuan responden diberikan kembali soal post test yang berjumlah 20 soal.

Analisis data menggunakan uji T-test Dependent danuji T-test Independent.

\section{HASIL}

Karakteristik Responden

Tabel 4.1 Distribusi umur responden setiap kelompok di MAS Darul Ihsan Kabupaten Aceh Besar ProvinsiAceh

\begin{tabular}{cccccc}
\hline No & Umur & $\begin{array}{c}\text { Audio } \\
\text { visual }\end{array}$ & $\%$ & Leaflet & $\%$ \\
\hline 1. & 15 tahun & 16 & $17,2 \%$ & 16 & $17,2 \%$ \\
\hline 2. & 16 tahun & 36 & $38,7 \%$ & 38 & $40,9 \%$ \\
\hline 3. & 17 tahun & 34 & $36,6 \%$ & 32 & $34,4 \%$ \\
\hline 4. & 18 tahun & 5 & $5,4 \%$ & 5 & $5,4 \%$ \\
\hline 5. & 19 tahun & 1 & $1,1 \%$ & 1 & $1,1 \%$ \\
\hline 6. & 20 tahun & 1 & $1,1 \%$ & 1 & $1,1 \%$ \\
\hline
\end{tabular}

Berdasarkan tabel 4.1 diatas dapat dilihat bahwa rata-rata tingkat umur responden pada kedua kelompok adalah 16 tahun dimana, kelompok audio visual sebanyak (38,7\%) sedangkan kelompok leaflet sebanyak (40,9\%).

Tabel 4.2 Distribusi jenis kelamin responden setiap kelompok di MAS Darul Ihsan Kabupaten Aceh Besar ProvinsiAceh

\begin{tabular}{lllll}
\hline No & $\begin{array}{c}\text { Jenis } \\
\text { Kelamin }\end{array}$ & Audio Visual & Leaflet & $\%$ \\
\hline 1. & Laki-laki & 46 & 46 & $49,4 \%$ \\
\hline 2. & Perempuan & 47 & 47 & $50,6 \%$ \\
\hline & Jumlah & 93 & 93 & $100 \%$ \\
\hline
\end{tabular}

Berdasarkan tabel 4.2 diatas dapat dilihat bahwa mayoritas jenis kelamin pada kedua kelompok dalah perempuan yaitu $51,6 \%$.

\section{Analisis Univariat}

Tabel 4.3 Distribusi tingkat pengetahuan sebelum intervensi setiap kelompok di MAS Darul Ihsan Kabupaten Aceh Besar Provinsi Aceh

\begin{tabular}{llllll}
\hline No & Media & $\begin{array}{l}\text { Rata- } \\
\text { Rata }\end{array}$ & $\begin{array}{l}\text { Standar } \\
\text { Deviasi }\end{array}$ & Minimum & Maksimum \\
\hline 1. & $\begin{array}{l}\text { Audio } \\
\text { visual }\end{array}$ & 69,80 & 11,12 & 50,00 & 90,00 \\
\hline 2. & Leaflet & 65,20 & 11,55 & 45,00 & 95,00 \\
\hline
\end{tabular}

Berdasarkan tabel 4.3 diatasmenunjukkan bahwa nilai rata-rata pengetahuan sebelum intervensi pada kelompok audio visual adalah 69,80 dan kelompok leaflet adalah 65,20.

Tabel 4.4 Distribusi tingkat pengetahuansesudah intervensi setiap kelompok di MAS Darul Ihsan Kabupaten Aceh Besar Provinsi Aceh

\begin{tabular}{cccccc}
\hline No & Media & $\begin{array}{c}\text { Rata- } \\
\text { Rata }\end{array}$ & $\begin{array}{c}\text { Standar } \\
\text { Deviasi }\end{array}$ & Minimum & Maksimum \\
\hline 1. & $\begin{array}{l}\text { Audio } \\
\text { visual }\end{array}$ & 88,76 & 9,05 & 60,00 & 100,00 \\
\hline 2. & Leaflet & 80,10 & 12,10 & 50,00 & 100,00 \\
\hline
\end{tabular}

Berdasarkan tabel 4.4 diatas menunjukkan bahwa nilai rata-rata pengetahuan sesudah intervensi pada kelompok audio visual adalah 88,76 dan kelompok leaflet adalah80,10.

Tabel 4.5 Distribusi perubahan tingkat pengetahuan sebelum dan sesudah intervensi setiap kelompok di MAS Darul Ihsan Kabupaten Aceh Besar Provinsi Aceh

\begin{tabular}{clcccc}
\hline No & Media & $\begin{array}{c}\text { Rata- } \\
\text { Rata }\end{array}$ & $\begin{array}{c}\text { Standar } \\
\text { Deviasi }\end{array}$ & Minimum & Maksimum \\
\hline 1. & $\begin{array}{l}\text { Audio } \\
\text { visual }\end{array}$ & 18,96 & 10,80 & $-5,00$ & 45,00 \\
\hline 2. & Leaflet & 14,94 & 15,93 & $-25,00$ & 45,00 \\
\hline
\end{tabular}

Berdasarkan tabel 4.5 diatas menunjukkan bahwa perubahan rata-rata tertinggi yaitu pada kelompok audio visual yaitu 18,96. 
Analisis Bivariat

Tabel 4.6 Hasil uji statistik (Uji Wilcoxon) tingkat pengetahuan sebelum dan sesudah intervensi pada kelompok Audio Visual di MAS Darul Ihsan Kabupaten Aceh Besar Propinsi Aceh ( $\mathrm{N}=17)$

\begin{tabular}{cccc}
\hline \multirow{2}{*}{$\begin{array}{c}\text { Kelompok } \\
\text { Audio } \\
\text { Visual }\end{array}$} & \multicolumn{2}{c}{ Mean Rank } & Sig \\
\cline { 2 - 3 } & Negative & Positif & \\
\hline $\begin{array}{c}\text { Sebelum- } \\
\text { sesudah }\end{array}$ & 6,50 & 47,39 & 0,000 \\
\hline
\end{tabular}

Berdasarkan tabel 4.6 diatas dapat dilihat bahwa nilai signifikansi lebih kecil dari nilai alpha $(0,000<0.05)$ maka Hoditolak. Jadi, dapat disimpulkan bahwa ada perbedaan rata-rata tingkat pengetahuan pada kelompok audiovisual sebelum intervensi dengan tingkat pengetahuan sesudah intervensi. Ternyata, setelah dilakukan intervensi, rata-rata tingkat pengetahuan responden yang mengalami peningkatan yaitu sebesar 47,39.

Tabel 4.7 Hasil uji statistik (UjiWilcoxon) tingkat pengetahuansebelum dan sesudah intervensi pada kelompok Leaflet di MAS Darul Ihsan Kabupaten Aceh Besar Provinsi Aceh (N=17)

\begin{tabular}{cccc}
\hline \multirow{2}{*}{$\begin{array}{c}\text { Kelompok } \\
\text { Audio Visual }\end{array}$} & \multicolumn{2}{c}{ Mean Rank } & \multirow{2}{*}{ Sig } \\
\cline { 2 - 3 } & Negative & Positif & \\
\hline Sebelum-sesudah & 36,20 & 45,01 & 0,000 \\
\hline
\end{tabular}

Berdasarkan tabel 4.7 diatas dapat dilihat bahwa nilai signifikansi lebih kecil dari nilai alpha $(0,000<0,05)$ maka Ho ditolak. Jadi, dapat disimpulkan bahwa ada perbedaan rata-rata tingkat pengetahuan pada kelompok leaflet sebelum intervensi dengan tingkat pengetahuan sesudah intervensi. Ternyata, setelah dilakukan intervensi, rata-rata tingkat pengetahuan responden yang mengalami peningkatan yaitu sebesar 45,01.

Tabel 4.8 Hasil uji statistik (Uji Mann Witney)tingkat pengetahuansebelum dan sesudah intervensi pada kelompok Audio Visual dan kelompok Leaflet di MAS Darul Ihsan Kabupaten Aceh Besar Provinsi Aceh ( $\mathrm{N}=34)$

\begin{tabular}{cccc}
\hline \multirow{2}{*}{ Perbedaan } & \multicolumn{2}{c}{ Mean Rank } & \multirow{2}{*}{ Sig. } \\
\cline { 2 - 3 } & Audio & Leaflet & \\
\hline Selisih & 99,33 & 87,67 & 0,137 \\
\hline
\end{tabular}

Berdasarkan tabel 4.8 diatas dapat dilihat bahwa terdapat perbedaan perubahan nilai mean dari skor pengetahuan tentang HIV/AIDS antara media leaflet dengan audio visual. Hasil uji statistik menunjukkan bahwa sig $=0,137(0,137>0,05)$, maka Ho diterima. Jadi, dapat disimpulkan bahwa tidak ada perbedaan antara rata-rata tingkat pengetahuan kelompok audiovisual dengan kelompok leaflet sebelum dan sesudah intervensi.

\section{PEMBAHASAN}

Perbedaan rata-rata tingkat pengetahuan sebelum
dan sesudah intervensi pada kelompok audio visual
Hasil penelitian yang dipaparkan berdasarkantabel 4.6 diatas dapat dilihat bahwa nilai signifikansi lebih kecil dari nilai alpha $(0,000<0,05)$ maka Ho ditolak. Jadi, dapat disimpulkan bahwa ada perbedaan rata-rata tingkat pengetahuan pada kelompok audiovisual sebelum intervensi dengan tingkat pengetahuan sesudah intervensi. Ternyata, setelah dilakukan intervensi, rata-rata tingkat pengetahuan responden yang mengalami peningkatan yaitu sebesar 47,39.

Penelitian ini sejalan dengan penelitian yang dilakukan oleh Tarigan (2016) bahwadiperoleh nilai rata-rata pengetahuan sebelum dilakukan promosi kesehatan dengan media video dibandingkan dengan nilai rata-rata pengetahuan sesudah dilakukan promosi kesehatan dengan media video mengalami perubahan, dapat disimpulkan bahwa ada efektivitas promosi kesehatan dengan media video terhadap perubahan tingkat pengetahuan jika dibandingkan antar tingkat pengetahuan sebelum diberi promosi kesehatan dengan media video dan sesudah diberi promosi kesehatan dengan media video diperoleh nilai $\mathrm{p}<0,001$.

Media audio visual merupakan salah satu alat bantu yang dapat meningkat pengetahuan seseorang. Media audio visual merupakan media yang dapat memperjelas dan mempermudah penyampaian pesan agar tidak terlalu verbalistis serta mengatasi keterbatasan waktu, ruang dan daya indera peserta didik maupun instruktur ${ }^{31}$.

Pengetahuan responden dipengaruhi oleh proses belajar dimana media yang digunakan dalam pembelajaran memberikan efek yang berbeda bagi responden sesuai dengan pengalaman, sehingga mereka lebih mudah memahaminya, sesuai dengan penelitain Hamida (2012) yang menyatakanbahwa media dalam proses pembelajaran akan menyebabkan proses pembelajaran menjadi lebih menarik perhatian sehingga dapat mudah dipahami dan menyebabkan sasaran tidak cepat bosan.

Berdasarkan hal diatas peneliti dapat beramsumsi bahwa rata-rata tingkat pengetahuan sebelum dan sesudah intervensi pada kelompok audio visual ini berbeda. Tingkat pengetahuan responden setelah intervensi mengalami peningkatan. Hal ini didasari karena sebelum intervensi responden belum pernah mengetahui secara detail tentang HIV/AIDS terutama cara penularannya karena hal ini diketahui dari 20 soal test yang diberikan oleh peneliti, responden paling banyak tidak bisa menjawab soal tentang cara penularan HIV/AIDS. Kebanyakan dari responden hanya pernah mendengar secara sepintas tentang HIV/AIDS dan bahkan ada yang tidak 
mengetahuinya sama sekali. Namun, setelah intervensi responden sudah mengetahui dan dapat memahami bahwa HIV/AIDS dapat menular, menyerang sistem kekebalan tubuh, serta responden sudah mengetahui cara pencegahannya.

\section{Perbedaan rata-rata tingkat pengetahuan sebelum dan sesudah intervensi pada kelompok leaflet}

Berdasarkan tabel 4.7 diatas dapat dilihat bahwa nilai signifikansi lebih kecil dari nilai alpha $(0,000<0,05)$ maka Ho ditolak. Jadi, dapat disimpulkan bahwa ada perbedaan rata-rata tingkat pengetahuan pada kelompok leaflet sebelum intervensi dengan tingkatpengetahuan sesudah intervensi. Ternyata, setelah dilakukan intervensi, rata-rata tingkat pengetahuan responden yang mengalami peningkatan yaitu sebesar 45,01.

Penelitian ini sejalan dengan penelitian yang dilakukan oleh Zuhdi (2015) yang membuktikan bahwa media leaflet efektif meningkatkan pengetahuan dan sikap remaja tentang HIV/AIDS di SMA Surakarta menunjukkan terjadi peningkatan rerata nilai pengetahuan dan sikap remaja dari sebelum diberi perlakuan penyuluhan dengan media leaflet dibandingkan dengan sesudah diberi perlakuan penyuluhan denga media leaflet.

Pendidikan kesehatan adalah suatu penerapan konsep pendidikan di dalam bidang kesehatan. Dilihat dari segi pendidikan, pendidikan kesehatan adalah suatu pedagogik praktis atau praktek pendidikan. Oleh sebab itu konsep pendidikan kesehatan adalah konsep pendidikan yang diaplikasikan pada bidang kesehatan $^{13}$.

Menurut asumsi peneliti penggunaan media leaflet sangat baik digunakan untuk membantu pembelajaran karena leaflet dapat dibaca berulang-ulang dengan diberikan leaflet responden dapat membaca kapan saja, dapat dibawa kemana saja, sehingga berpengaruh terhadap daya ingat dalam jangka waktu yang lebih lama.

Media leaflet mempunyai beberapa keunggulan diantaranya adalah menarik untuk dilihat, mudah dimengerti, lebih ringkas dalam penyampaian informasi, merangsang imajinasi dalam pemahaman isi leaflet dan dapat dibaca oleh khalayak yang lebih luas. Disamping memiliki keunggulan media leaflet juga memiliki beberapa kelemahan diantaranya adalah jika salah dalam desain maka leaflet tersebut tidak akan menarik untuk dibaca, media leaflet juga dapat menimbulkan kebosanan. Bentuk kelemahan yang lain adalah untuk media leaflet yang dicetak membutuhkan biaya yang lebih mahal.

\section{Perbedaan tingkat pengetahuan sesudah intervensi pada kelompok audio visual dan kelompok leaflet.}

Berdasarkan tabel 4.8 diatas dapat dilihat bahwa terdapat perbedaan perubahan nilai mean dari skor pengetahuan tentang HIV/AIDS antara media leaflet dengan audio visual. Hasil uji statistik menunjukkan bahwa sig $=0,137(0,137>0,05)$, maka Ho diterima.
Jadi, dapat disimpulkan bahwa tidak ada perbedaan antara rata-rata tingkat pengetahuan kelompok audiovisual dengan kelompok leaflet sebelum dan sesudah intervensi.

Berdasarkan hipotesis diatas maka hal ini sebanding dengan kenyataan bahwa pengetahuan responden menggunakan media audio visual dan media leaflet tidak terdapat perbedaan secara signifikan. Hal ini dapat dibuktikan setelah melakukan intervensi nilai signifikansi $=0,137$.

Penelitian ini tidak sejalan dengan penelitian Muthmainnah (2015) yang menyatakan bahwa penyuluhan menggunakan media audio visual lebih efektif meningkatkan pengetahuan responden daripada media leaflet.

Media pendidikan kesehatan adalah semua sarana atau upaya untuk menampilkan pesan atau informasi yang ingin disampaikan oleh komunikator melalui media elektronika (TV, komputer, film, video, CD, VCD dan sebagainya) sehingga sasaran dapat meningkatkan pengetahuannya dan pada akhirnya diharapkan dapat meningkatkan pengetahuan tentang kesehatan.

Secara umum pengetahuan dipengaruhi oleh proses belajar dimana media yang digunakan dalam pembelajaran memberikan efek yang berbeda, sehingga lebih mudah dipahami. Pada umumnya pengetahuan dimulai dari pengalaman dan informasi yang disampaikan oleh guru, orang tua, teman, buku dan media massa.

Berdasarkan penjelasan diatas, peneliti dapat berasumsi bahwa penggunaan media audio visual dan media leaflet sama pengaruhnya terhadap tingkat pengetahuan responden tentang HIV/AIDS, karena dengan adanya kedua media tersebut responden lebih mudah untuk mencerna materi yang disampaikan.

Berdasarkan pengamatan peneliti selama proses penelitian dengan menggunakan media audio visual penyampaian informasinya lebih menarik karena dapat menimbulkan kesan ruang dan waktu serta penggambarannya bersifat 3 dimensi sehingga suara yang dihasilkan dapat menimbulkan realita pada gambar dalam bentuk ekspresi murni. Oleh sebab itu, media audio visual tidak membuat responden bosan.

Sedangkan media leaflet selembaran kertas yang mengandung informasi yang jelas, singkat dan mudah dimengerti. Selain tulisan dalam leaflet juga terdapat gambar-gambar sehingga bisa menarik minat responden untuk membacanya. Leaflet juga bisa dibaca berulang-ulang dan mudah dibawa kemanapun responden pergi.

Kedua faktor yang telah dipaparkan diatas, sedikitnya telah menggambarkan realita dan telah mempengaruhi pengetahuan responden terkait informasi tentang HIV/AIDS. Secara umum berdasarkan nilai rata-rata yang diperoleh kedua kelompok tersebut tidak terdapat perbedaan yang signifikan dan dapat dikatakan relatif sama pengaruh media audio visual dan medialeaflet terhadap tingkat 
pengetahuan remaja MAS Darul Ihsan tentang HIV/AIDS.

\section{KESIMPULAN}

1. Ada perbedaan rata-rata tingkat pengetahuan pada kelompok audiovisual sebelum intervensidengan tingkat pengetahuan sesudah intervensi $(0,000<0,05)$.

2. Ada perbedaan rata-rata tingkat pengetahuan pada kelompok leaflet sebelum intervensidengan tingkat pengetahuan sesudah intervensi $(0,000<0,05)$.

3. Tidak ada perbedaan antara rata-rata tingkat pengetahuan kelompok AudioVisual dengan kelompok Leaflet sebelum intervensi(0,137>0,05).

\section{DAFTAR PUSTAKA}

World Health Organization (WHO). 2015. The Global Prevalence of Anaemina in 2011. Geneva: World Health Organization.

Kemenkes, RI. 2015. Profil Kesehatan Indonesia tahun 2014. Jakarta: Kemekes RI.

BKKBN. $2017 . \quad$ Info Demografi. https://www.bkkbn.go.id/pocontent/uploads/iNFO_DEMOGRAFI_2017.pd fDiakses pada tanggal 30 November 2017

World Health Organization (WHO). 2016. Monitoring Health of the SDGs. France: World Health Organization.

Nugroho, M, dkk. 2010.Catatan Kuliah Ginekologi dan Obsetri(Obgyn). Yogyakarta: Nuha Medika.

Kemenkes. 2016. Informasi Pusat Data dan Informasi Kementrian Kesehatan RI.
Depkes Ri. 2014. Pedoman Nasional Tatalaksana Klinis Infeksi HIV dan Terapi Antiretroviral Pada Orang Dewasa.

Tarigan, Eka Ristin (2016). Efektivitas Promosi Kesehatan Dengan Media Leaflet Dan Video Terhadap Pengetahuan Dan Sikap Remaja Tentang Hiv/Aids Di Sma Negeri 1 Berastagi Tahun 2016.

Hermawan, zaman dan riyana (2007). Media pembelajaran sekolah dasar. Penerbit: PT. Refika Aditama.

Hamida, K, Siti, Mutalizamah. 2012. Efektifitas Penyuluhan Gizi dengan Media Komik untuk Meningkatkan Pengetahuan tentang Keamanan Makanan Jajanan Sekolah Siswa Sekolah Dasar. Jurnal Kesmas, Unnes,8(1): 69-76.

Zuhdi, (2015). Pengaruh Pendidikan Kesehatan dengan Media Leaflet terhadap Tingkat Pengetahuan dan Sikap Siswa tentang Pencegahan HIV/AIDS di SMA Muhammdiyah Surakarta Tahun 2015.

Muthmainnah, Fitriyah Nafsiyah (2015). Pengaruh Penyuluhan Dengan Media Audio Visual Dan Leaflet Terhadap Pengetahuan Ibu Tentang Pemberian Makanan Pendamping ASI Tahun 2015. 